[Текст] / А. С. Аведисова, Р. В. Ахапкин, В. И. Ахапкина, Н. И. Вериго // Рос. психиатр. журн. - 2001. - № 1. C. $46-53$.

10. Список неефективних ліків [Електронний ресурс]. - Режим доступу: http://topfiles.timedosuga.com/ $? \mathrm{p}=9031$

11. Яковлєва, Л. В. Церебропротекція в аспекті доказової медицини: церебролізин та пірацетам [Текст] / Л. В. Яковлєва, А. В. Рибка // Управління, економіка та забезпечення якості в фармації. - 2013. - № 5. - С. 59-65. Режим доступу: http://nbuv.gov.ua/UJRN/Uezyaf_2013_5_11

\section{References}

1. Nakaz «Pro zatverdzhennja Koncepcii' rozvytku farmacevtychnogo sektoru galuzi ohorony zdorov'ja Ukrai'ny na 2011-2020 roky» (2010). MOZ Ukrai'ny, 769. Available at: http://www.moz.gov.ua/ua/portal/dn_20100913_769.html

2. Nakaz «Galuzeva programa standartyzacii' medychnoi' dopomogy na period do 2020 roku» (2011). MOZ Ukrai'ny, 597. Available at: http://www.moz.gov.ua/ua/portal/ dn_20110916_597.html

3. Martynenko, Ja. A. (2016). Epidemiologichna struktura zahvorjuvanosti ditej na cerebral'nyj paralich. Simejna medycyna. Perspektyvy ta shljahy podal'shogo rozvytku. Kompleksnyj pidhid do pytan' reabilitacii'. Novitni tendencii' likuvannja ta profilaktyky dermatovenerologichnyh problem $\mathrm{v}$ ramkah dokazovoi' medycyny. Lviv, 63-64.
4. Azars'kyj, I. M., Azars'ka, O. O. (2002). Dytjachyj cerebral'nyj paralich, nadbana slabkorozumovist' ta pedagogichna zanedbanist': Social'no-reabilitacijni aspekty dlja hvoryh v suspil'stvi. Khmelnyc: VAT "Vyd-vo "Podillja", 159.

5. Moisejenko, R. O., Sokolovs'ka, Ja. I., Kul'chyc'ka, T. K., Buhanovs'ka, T. M. (2010). Analiz ta tendencii' zahvorjuvanosti dytjachogo naselennja Ukrai'ny. Sovremennaja pedyatryja, 3 (31), 13-17.

6. Orlova, N. M. (2011). Medyko-social'ne obg'runtuvannja restrukturyzacii' merezhi ambulatorno-poliklinichnyh zakladiv iz vrahuvannjam medyko-demografichnyh osoblyvostej regioniv. Kyiv, 396.

7. Gorachuk, V. V. (2014). Medyko-social'ne obguntuvannja modeli systemy upravlinnja jakistju medychnoi' dopomogy. Kyiv, 391.

8. Paramosh, O. V. (2008). Optymizacija likars'kogo zabezpe-chennja hvoryh z rozladamy psyhiky. Lviv, 21.

9. Avedisova, A. S., Ahapkin, R. V., Ahapkina, V. I., Verigo, N. I. (2001). Analiz zarubezhnyh issledovanij nootropnyh preparatov (na primere piracetama). Ros. psihiatr. zhurn., 1, 46-53.

10. Spysok neefektyvnyh likiv. Available at: http://topfiles. timedosuga.com $/$ ? $=9031$

11. Jakovljeva, L. V., Rybka, A. V. (2013). Cerebroprotekcija $\mathrm{v}$ aspekti dokazovoi' medycyny: cerebrolizyn ta piracetam. Upravlinnja, ekonomika ta zabezpechennja jakosti v farmacii', 5, 59-65. Available at: http://nbuv.gov.ua/UJRN/ Uezyaf_2013_5_11

Рекомендовано до публікачії д-р фарм. наук, професор Парновський Б. Л. Дата надходження рукопису 09.09.2016

Парамош Олена Вікторівна, кандидат фармацевтичних наук, доцент, кафедра організації і економіки фармації, технології ліків та фармакоекономіки ,Львівський національний медичний університет ім. Данила Галицького, вул. Пекарська, 69, м. Львів, Україна, 79010

E-mail: elena_paramosh@mail.ru

\title{
УДК 615.015.6:343.575:351.761.3
}

\section{ОРГАНІЗАЦІЯ ФАРМАЦЕВТИЧНОГО ЗАБЕЗПЕЧЕННЯ ВІЙСЬКОВОСЛУЖБОВЦІВ, ЯКІ БРАЛИ УЧАСТЬ У БОЙОВИХ ДІЯХ, НА ЗАСАДАХ ФАРМАЦЕВТИЧНОГО ПРАВА}

\author{
(C) А. О. Гудзенко, В. В. Шаповалов, О. В. Семенькова, В. О. Шаповалова, \\ В. В. Шаповалов, Д. В. Москаленко
}

У статті наведено сучасний стан медико-фармацевтичного забезпечення пільгових категорій населення Украӥни, до яких чинним законодавством віднесено військовослужбовців, щчо брали участь у проведенні антитерористичної операції. Узагальнено судово-фармацевтичну практику щчодо порушень прав на доступність для пільгового контингенту населення (учасників бойових дій антитерористичної операції) лікарських засобів. Проведено аналіз чинного законодавства Украйни щцодо забезпечення військовослужбовиів у сфері охорони здоров'я.

Мета. Провести аналіз організації фармацевтичного забезпечення військовослужбовців, щзо брали участь у бойових діях, шляхом узагальнення судово-фармацевтичної практики.

Методи. Під час проведення досліджень використовувалися системний, нормативно-правовий, опитувальний, документальний та судово-фармачевтичний методи аналізу.

Результати дослідження. Встановлено, щзо внаслідок проведення бойових дій в Україні велика кількість військовослужбовців потребує медичної та фармацевтичної допомоги. Більше 12 тис. осіб вже пройшли курс лікування у медичних закладах Украӥни, проте залишається актуальним забезпечення поранених та хворих військовослужбовців необхідною фармакотерапією в амбулаторних умовах. Чинним законодавством Украӥни гарантовано безоплатне надання лікарських засобів учасникам бойових дій. Наведено приклади із судово-фармачевтичної практики щуодо надання медико-фармацевтичної допомоги учасникам бойових дій за кордоном та в Украйні. Запропоновано ряд організаційно-правових заходів, завдяки яким можливо оптимізувати взаємодію у ланцңюзі «лікар - пацієнт (учасник бойових дій) провізор» та підвищити рівень фармацевтичного забезпечення військовослужбовців, які брали участь у бойових діях. 
Висновки. В ході судово-фармацевтичних досліджень виявлено проблему несвоєчасного забезпечення лікарськими засобами військовослужбовців, які брали участь в антитерористичній операції.

Ключові слова: фармацевтичне право, судова фармація, пільги, лікарські засоби, обіг, режим контролю

The article presents the current state of medical and pharmaceutical provision for privileged categories of citizens of Ukraine, which current legislation referred soldiers who took part in anti-terrorist operations. Overviewed forensic and pharmaceutical practice on the availability medicines to privileged contingent of the population (combatants of the counterterrorist operation). Analyzed the current legislation of Ukraine to provide military healthcare.

Goal. To conduct an analysis of pharmaceutical provision for servicemen who participated in the fighting by summarizing the forensic and pharmaceutical practice.

Methods. During the studies used systemic, legal, questionnaire, documentary and forensic methods for pharmaceutical analysis.

Research results. Established that as a result of fighting in Ukraine a large number of soldiers in need of medical and pharmaceutical care. More than 12 thousand people have already been treated in medical institutions of Ukraine, but remains relevant provision of wounded and sick soldiers' necessary pharmacotherapy in the outpatient setting. The current legislation of Ukraine guaranteed the free provision of drugs for combatants. Examples of pharmaceutical and forensic practice in the provision of medical and pharmaceutical care combatants abroad and in Ukraine. A number of organizational and legal measures that make possible to optimize the interaction in the chain "doctor - patient (combatant) - pharmacist" and increase pharmaceutical provision for servicemen who participated in the fighting.

Conclusions. During the forensic and pharmaceutical research revealed the problem of delayed medical supply to troops who took part in anti-terrorist operations.

Keywords: pharmaceutical law, forensic pharmacy, benefits, medicines circulation, control regime.

\section{1. Вступ}

В сучасних умовах перед Міністерством охорони здоров’я (МО3) України, Міністерством внутрішніх справ (МВС) України та Міністерством оборони (МO) України стоїть завдання забезпечення учасників бойових дій (УБД), які звільнені до запасу, сучасною медико-фармацевтичною та соціально-економічною допомогою через 29 госпіталів, де бійці проходять реабілітаційні процеси [1], а також збереження їх прав, життя та здоров'я, як пацієнтів, що потребують своєчасного забезпечення лікарськими засобами (ЛЗ) різних клініко-фармакологічних груп (КФГ), класифікаційноправових груп (КПГ) та номенклатурно-правових груп (НПГ), зокрема тих, що мають психоактивні властивості. На наш погляд, це питання повинно вирішуватися шляхом прийняття цілісної стратегії комплексного реформування системи охорони здоров'я, в т. ч. фармацевтичного сектору. В основі оновленої медицини i фармації повинні зосереджуватися принципи гуманності до прав та потреб кожного громадянина, як пацієнта. При цьому пільгові категорії громадян (УБД антитерористичної операції (АТО); ліквідатори аварії на Чорнобильській атомній електростанції (ЧАЕС); інваліди I і II групи та ін.) заслуговують на своєчасно надану медичну допомогу та безперешкодний доступ до якісних, безпечних, ефективних, життєво необхідних Л3 [2].

2. Постановка проблеми у загальному вигляді, актуальність теми та її зв'язок із важливими науковими чи практичними питаннями

За даними Організації Об'єднаних Націй в Україні триває АТО із проведенням бойових дій, внаслідок чого більше 1,1 млн. українців були змушені покинути свої житлові помешкання та роботу, близько 5 тис. громадян загинуло і більше
12 тис. осіб поранено, 33 \% 3 яких мають ураження голови $[1,3]$.

Дослідження фахівців медичного центру з вивчення черепно-мозкової травми (США, штат Техас) свідчать, що понад 50 \% усіх поранень УБД отримують при використанні вибухових речовин; отримані черепно-мозкові травми призводять до змін в мозковому кровообігу; травми головного мозку погіршують компенсаторні реакції організму, що призводить до розвитку вторинних інсультів [4].

Отже, поранені УБД потребують надання своєчасної психіатричної, медичної (опіки і поранення вимагають сучасної нейрохірургічної допомоги) та фармацевтичної (забезпечення медикаментами) допомоги від територіальних КЗОЗ та аптечних закладів [1, 3], що здійснюють обіг ЛЗ всіх КПГ (наркотичні засоби: морфін, омнопон, трамадол; психотропні речовини: діазепам, фенобарбітал; сильнодіючі ЛЗ: димедрол та ін.).

3. Аналіз останніх досліджень і публікацій, в яких започатковано розв'язання даної проблеми i на які спирається автор

Питанням забезпечення медикаментами пільгових категорій громадян були присвячені публікації Пономаренка М. С. [5], Волоха Д. С. [6], Сятині М. Л. [7], Толочка В. М. [8], Гудзенка О. П. [9], Мнушко 3. М. [10], Немченко А. С. [11], Котвіцької А. А. [12].

4. Виділення невирішених раніше частин загальної проблеми, якій присвячена стаття

Проте дослідження сучасної організації медико-фармацевтичного забезпечення військовослужбовців, які брали участь у бойових діях (АТО), на засадах медичного та фармацевтичного права і судової фармації досі не проводилися. 


\section{5. Формулювання цілей (завдання) статті}

Метою роботи стало вивчення організації фармацевтичного забезпечення військовослужбовців, які брали участь у бойових діях (АТО), на підставі аналізу прикладів із судово-фармацевтичної практики.

6. Виклад основного матеріалу дослідження (методів та об'єктів) 3 обгрунтуванням отриманих результатів

Матеріалом дослідження виступали дані, отримані на базі 58 комунальних закладів охорони здоров'я (КЗОЗ), які підпорядковані Департаменту охорони здоров'я Харківської обласної державної адміністрації (ДОЗ ХОДА); 11 аптек комунальної форми власності та 7 аптек інших форм власності, що здійснюють обіг наркотичних засобів та психотропних речовин; чинне медичне та фармацевтичне законодавство України; інструкції для медичного застосування ЛЗ. Під час проведення досліджень використовувалися системний, нормативно-правовий, опитувальний, документальний та судово-фармацевтичний методи аналізу.

За даними MO3 України (станом на 10 липня 2016 р.) в мережі госпіталів ветеранів війни вже проліковано 12913 учасників АТО і ще 584 особи знаходиться на лікуванні. Разом 3 тим, на рис. 1 представлено області України, де найбільша кількість УБД отримала фармакотерапію в мережі госпіталів ветеранів війни [13].

Як видно 3 рис. 1, найбільша кількість УБД АТО отримали медико-фармацевтичну допомогу в Київській та Кіровоградській областях (відповідно 1506 і 1491 осіб).
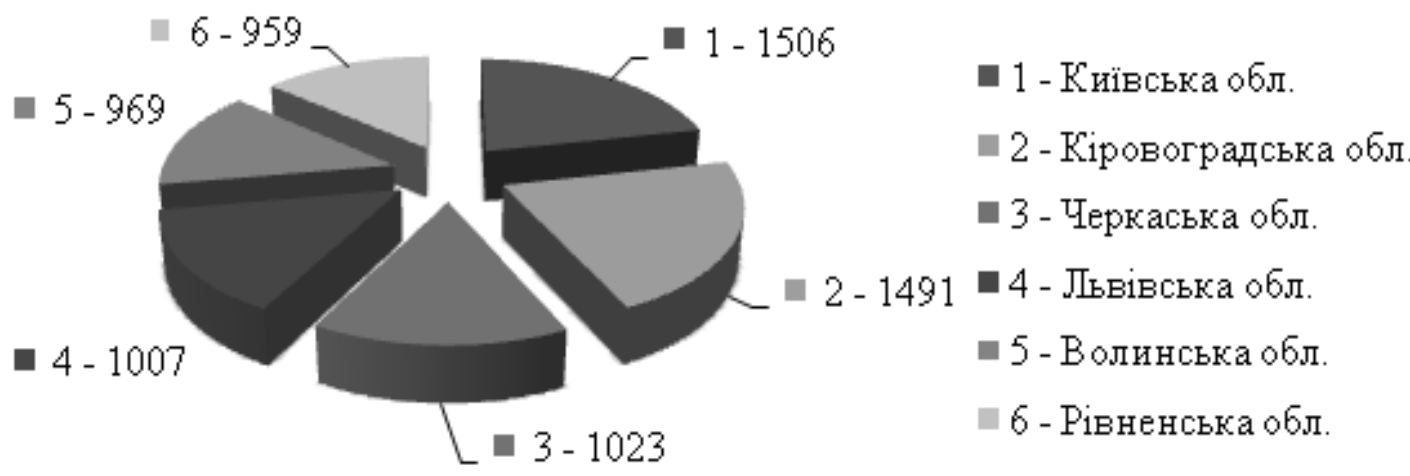

Рис. 1. Найбільша кількість пролікованих учасників бойових дій в мережі госпіталів ветеранів війни [13]

Узагальнюючи дані КЗОЗ «Обласний госпіталь ветеранів війни» встановлено, що у 2015 р. в Харківській області 8050 ветеранів війни усіх категорій (у т. ч. УБД АТО) отримали медикаменти безоплатно за пільговими рецептами для амбулаторного лікування на загальну суму 1261272,83 грн., що склало 156,68 грн. на одного ветерана.

Слід зазначити, що реабілітація постраждалих військовослужбовців - це довготривалий процес, що вимагає допомоги кваліфікованих лікарів та провізорів, які мають досвід саме $з$ надання відповідної допомоги УБД. Це потребує удосконалення підходів до підготовки медичних та фармацевтичних фахівців в рамках існуючих спеціальностей реабілітаційної медицини на зразок тієї, яка існує в країнах ЄC.

Вивчення досвіду лікарів військових госпіталів (приклад № 1) свідчить про важливість своєчасного надання медико-фармацевтичної допомоги постраждалим військовослужбовцям 3 подальшою їх тривалою реабілітацією за місцем проживання.

Приклад 1. На базі іспанського військового госпіталю (розташований в Афганістані) лікарями надавалася медико-фармацевтична допомога пораненим військовослужбовцям шляхом введення транексамової кислоти (міжнародна непатентована назва - транексамова кислота) протягом перших трьох годин. Внаслідок чого спостерігалася зупинка кровотечі у всіх без виключення пацієнтів (проявів несприятливих реакцій не виникало). Отриманий досвід лікарями рекомендовано до застосування в бойових умовах лікарям країн-членів НАТО [14]. Крім того, в подальшому для підвищення рівня фармакотерапії пораненим військовослужбовцям призначалися протибольові ЛЗ із КПГ «наркотичні засоби», «психотропні речовини», «загальна група».

У зв'язку з цим постає питання щодо оптимізації правовідносин у ланцюзі «лікар - пацієнт (УБД) - провізор - адвокат» 3 метою підвищення рівня забезпечення права військовослужбовців на здоров'я, отримання належної медичної, фармацевтичної та реабілітаційної допомоги в Україні.

Сучасна нормативно-правова база щодо пільгового забезпечення УБД ЛЗ представлена на рис. 2 [15-22].

Слід відзначити, що забезпечення військовослужбовців у сфері охорони здоров'я здійснюється на підставі положень Закону України «Про статус ветеранів війни, гарантії їх соціального захисту» (далі Закон) [17], яким передбачено пільги на ряд важливих медико-фармацевтичних послуг, що необхідні під час лікування та реабілітації УБД (табл. 1). 


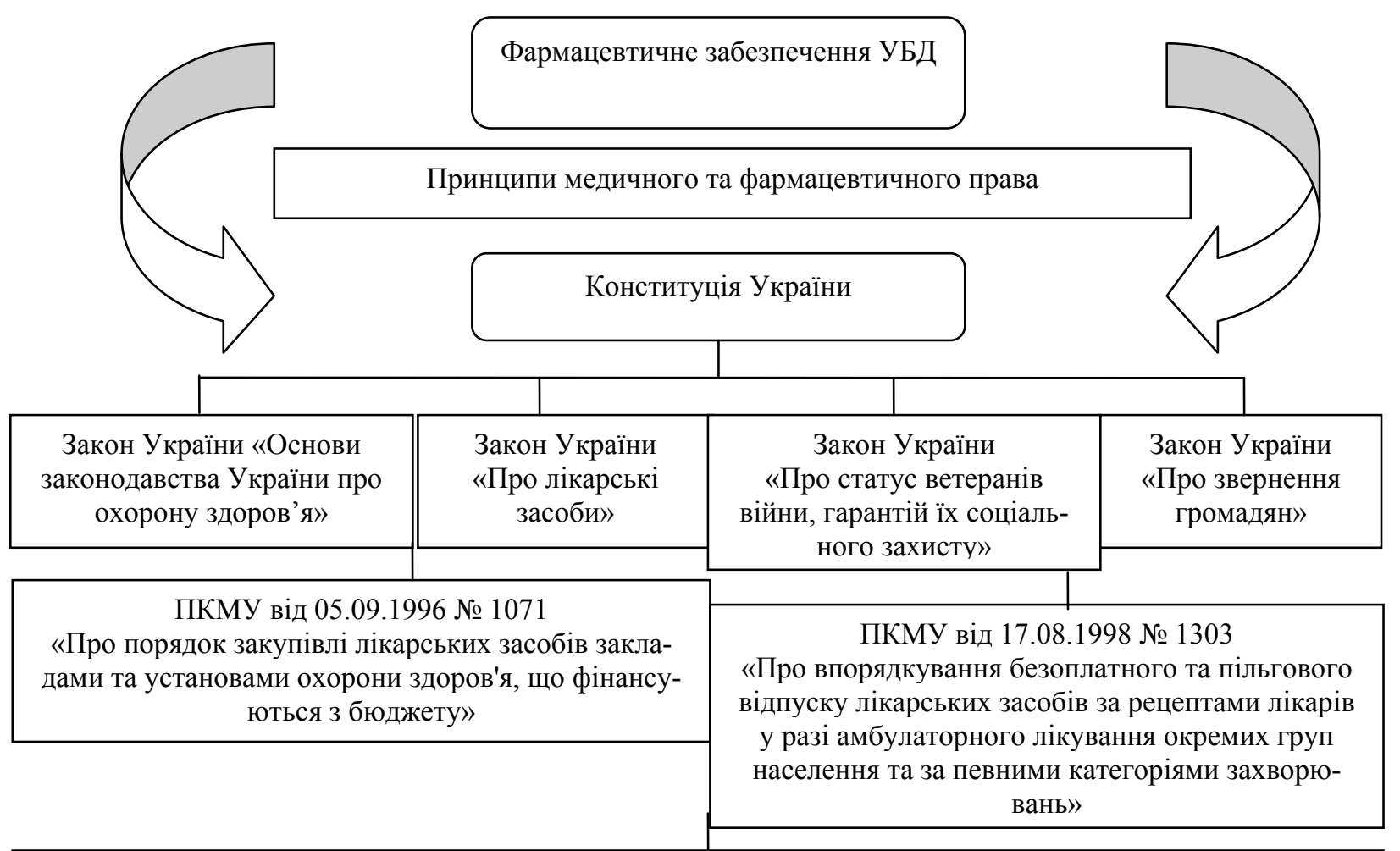

Наказ МОЗ України від 19.07.2005 № 360 «Про затвердження Правил виписування рецептів та вимогзамовлень на лікарські засоби і вироби медичного призначення, Порядку відпуску лікарських засобів і виробів медичного призначення з аптек та їх структурних підрозділів, Інструкції про порядок зберігання, обліку та знищення рецептурних бланків та вимог-замовлень»

Рис. 2. Нормативно-правова база щодо пільгового забезпечення учасників бойових дій лікарськими засобами [15-22]

Таблиця 1

Пільги для учасників бойових дій в сфері охорони здоров'я [17]

\begin{tabular}{|c|c|}
\hline Норма законодавства & Вид пільги \\
\hline п. 1 ч. 1 ст. 12 Закону & $\begin{array}{r}\text { безплатне одержання ліків, лікарських засобів, імунобіологічних препара- } \\
\text { тів та виробів медичного призначення за рецептами лікарів }\end{array}$ \\
\hline п. 2 ч. 1 ст. 12 Закону & $\begin{array}{r}\text { першочергове безплатне зубопротезування (за винятком протезування } 3 \\
\text { дорогоцінних металів) }\end{array}$ \\
\hline п. 3 ч. 1 ст. 12 Закону & $\begin{array}{c}\text { безплатне щорічне забезпечення санаторно-курортним лікуванням, а та- } \\
\text { кож компенсація вартості самостійного санаторно-курортного лікування }\end{array}$ \\
\hline п. 8 ч. 1 ст. 12 Закону & $\begin{array}{c}\text { користування при виході на пенсію (незалежно від часу виходу на пенсію) } \\
\text { чи зміні місця роботи поліклініками та госпіталями, до яких вони були } \\
\text { прикріплені за попереднім місцем роботи }\end{array}$ \\
\hline п. 9 ч. 1 ст. 12 Закону & $\begin{array}{r}\text { щорічне медичне обстеження і диспансеризація із залученням необхідних } \\
\text { спеціалістів }\end{array}$ \\
\hline п. 10 ч. 1 ст. 12 Закону & $\begin{array}{r}\text { першочергове обслуговування в лікувально-профілактичних закладах, } \\
\text { аптеках та першочергова госпіталізація }\end{array}$ \\
\hline
\end{tabular}

Проте, на підставі проведених судовофармацевтичних досліджень виявлено проблему щодо несвоєчасного забезпечення ЛЗ військовослужбовців, які брали участь в АТО, про що свідчить наведений нижче типовий приклад № 2 із судовофармацевтичної практики.
Приклад 2. На гарячу лінію ДОЗ ХОДА 29.04.2016 р. звернувся гр. А. (УБД АТО, інвалід III групи), який в КЗОЗ м. Харкова проходив лікування отриманих під час участі в АТО травм та вогнепальних поранень, 3 приводу відмови провізора аптеки ТОВ «А.» відпустити ЛЗ актовегін і нормовен 
за пільговими рецептами лікаря. Згідно чинного законодавства України УБД в аптечних закладах повинні безкоштовно отримувати ЛЗ за пільговими рецептами лікарів. Отже, після втручання фахівців ДОЗ ХОДА було направлено листа (на основі Закону України «Про звернення громадян») [18]) до головного лікаря КЗОЗ та завідувача аптеки ТОВ «А.» про необхідність поновлення прав гр. А., що базуються на принципах Конституції України [19], норм медичного та фармацевтичного права [23], а також постанови Кабінету Міністрів України (ПКМУ) від 17.08.1998
№ 1303 «Про впорядкування безоплатного та пільгового відпуску лікарських засобів за рецептами лікарів у разі амбулаторного лікування окремих груп населення та за певними категоріями захворювань» [22]. У подальшому провізором аптеки ТОВ «А.» недоліки, пов'язані 3 обігом пільгових рецептів та ЛЗ було усунуто, а пацієнту УБД АТО гр. А. ЛЗ актовегін і нормовен було відпущено.

Для більш детальної характеристики згаданих в прикладі № 2 ЛЗ визначено їх режим контролю (табл. 2) на території України.

Таблиця 2

Режим контролю ЛЗ із судово-фармацевтичної практики

\begin{tabular}{|c|c|c|c|c|c|c|c|}
\hline $\begin{array}{c}\text { Торговельна } \\
\text { назва Л3 }\end{array}$ & $\begin{array}{c}\text { Міжнародна } \\
\text { непатентова- } \\
\text { на назва Л3 }\end{array}$ & $\begin{array}{c}\text { Діюча речо- } \\
\text { винаЛ3 }\end{array}$ & $\begin{array}{l}\text { Лікарська } \\
\text { форма Л3 }\end{array}$ & $\begin{array}{c}\text { АТХ-код*, } \\
\text { КФГ ЛЗ }\end{array}$ & КПГ ЛЗ & НПГ ЛЗ & $\begin{array}{l}\text { НПГ ЛЗ } \\
\text { для УБД }\end{array}$ \\
\hline Актовегін & - & \begin{tabular}{|} 
Депротеїнізо- \\
ваний гемо- \\
дериват із \\
крові телят \\
\end{tabular} & $\begin{array}{l}\text { Розчин для } \\
\text { ін'єкцій }\end{array}$ & $\begin{array}{c}\text { С05СА53 } \\
\text { «Ангіопроте- } \\
\text { ктори» }\end{array}$ & Загальна & $\begin{array}{c}\text { За рецептом } \\
\text { ф-1, багато- } \\
\text { разовий }\end{array}$ & \multirow[b]{2}{*}{$\begin{array}{c}\text { Пільговий } \\
\text { рецепт ф-1 в } \\
\text { 2-х примір- } \\
\text { никах }\end{array}$} \\
\hline Нормовен & $\begin{array}{l}\text { Діосмін, } \\
\text { комб. }\end{array}$ & $\begin{array}{c}\text { Флавоноїдна } \\
\text { фракція, яка } \\
\text { містить діос- } \\
\text { мін і геспе- } \\
\text { ридин }\end{array}$ & Таблетки & \begin{tabular}{|} 
А16АХ «Інші \\
засоби, що \\
впливають на \\
травну сис- \\
тему та мета- \\
болічні про- \\
цеси» \\
\end{tabular} & Загальна & Без рецепта & \\
\hline
\end{tabular}

Примітка: *АТХ-код-анатомо-терапевтично-хімічна класифікачія.

На підставі даних табл. 2 з'ясовано, що за класифікаційно-правовою ознакою актовегін і нормовен відносяться до загальної групи. За номенклатурноправовою ознакою для пацієнтів, які не відносяться до пільгової категорії громадян, актовегін (р-н д/ін.) відпускається за багаторазовим рецептом ф-1, а нормовен - без рецепта, що свідчить про його доступність; для УБД зазначені ліки відпускаються за пільговим рецептом ф-1.
Слід відмітити, що питання своєчасної медичної допомоги та доступності життєво необхідних ліків для УБД обговорювалися керівництвом МО3 України на Всеукраїнській міжвідомчій науковопрактичній конференції «Медичне забезпечення антитерористичної операції: науково-організаційні та медико-соціальні аспекти» (14-15.07.2016 р., м. Київ), де також були висвітлені проблеми, наведені на рис. 3 [24].

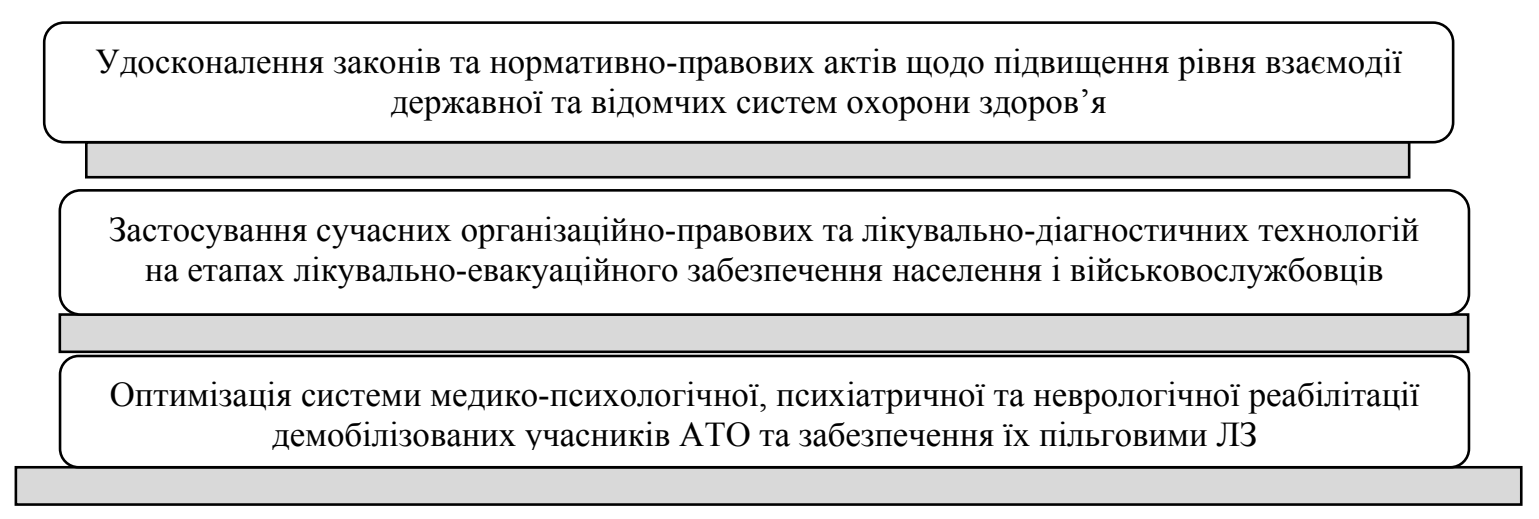

Рис. 3. Актуальні проблеми медико-фармацевтичного забезпечення учасників бойових дій антитерористичної операції [24]

Для своєчасного надання психіатричної допомоги учасникам АТО Богомолець О. В., Пінчук І. Я. і Друзь О. В. розроблено методичні рекомендації «Оптимізація підходів до надання психіатричної допомоги відповідно до сучасних потреб учасників бойових дій», в яких на основі вивченого досвіду інших країн, аналізу існуючої організаційної та кадрової складових системи надання психіатричної допомоги в Україні запропонована оптимізація підходів до надання психіатричної допомоги УБД. Крім цього, зазначені методичні рекомендації містять алгоритми практичних дій спеціалістів, задіяних у наданні допомоги військовослужбовцям щодо діагностики, медико-соціальної допомоги та профілактики бойових психічних травм на різних етапах 
здійснення зазначених заходів. Застосування зазначених у методичних рекомендаціях алгоритмів дозволить оптимізувати надання психіатричної допомоги на іï різних етапах та підвищить ефективність заходів щодо діагностики, лікування, реабілітації та профілактики розладів психіки та поведінки у бійців, які перебувають або перебували в зоні бойових дій [25].

Завдяки підтримки керівництва МО3 України 17.02.2016 р. фахівцями на базі Департаменту медичної допомоги проведено обмін досвідом із ізраїльськими лікарями, військовими психологами та психіатрами у здійсненні функціональної діагностики, реа- німації, інтенсивної фармакотерапії, медикопсихологічної, психолого-неврологічної та фізичної реабілітації учасників бойових дій [26].

При інспектуванні обласної травматологічної лікарні м. Харків губернатор Райнін I. наголосив на впровадженні пільг в приватних аптеках та кабінеті томографії для учасників АТО, а також поліпшити умови та раціон [27].

Отже, для підвищення рівня фармацевтичної допомоги при забезпеченні учасників АТО ЛЗ всіх КПГ запропоновано організаційно-правові заходи, що представлені на рис. 4.

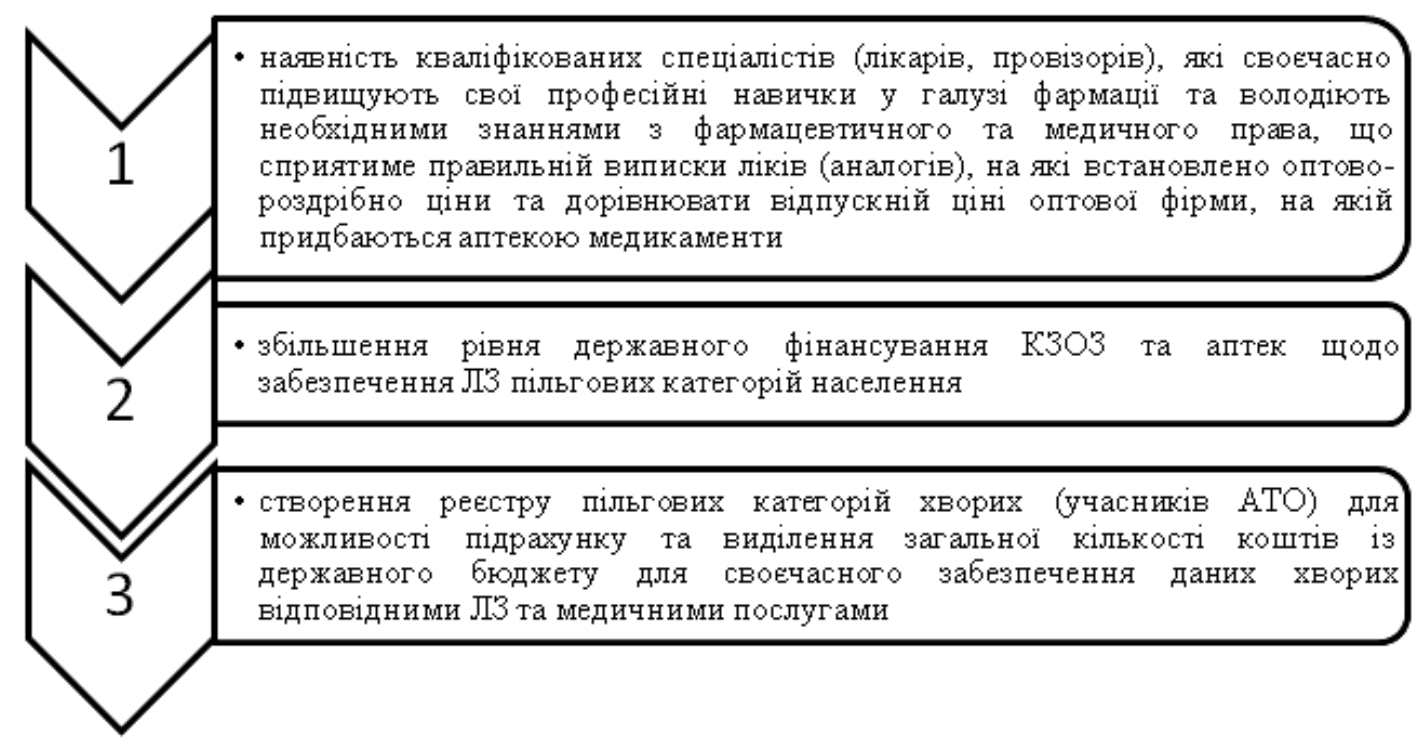

Рис. 4. Організаційно-правові заходи щодо забезпечення УБД пільгами

Разом $з$ тим, ДОЗ ХОДА приділяє особливу увагу проблемним питанням, що виникають у ланцюзі правовідносин «лікар - пацієнт (УБД) - провізор адвокат», які вирішуються шляхом виконання законодавства України і нормативно-правових актів. Зокрема, на 17-18 листопада 2016 р. в м. Харкові заплановано проведення XIII міждисциплінарної та міжгалузевої науково-практичної конференції за участю міжнародних спеціалістів «Слобожанські читання. Фармацевтичне і медичне право України: інновації, якість, безпека, доступність і перспективи розвитку судової фармації і страхової медицини» (реєстраційне посвідчення УкрIНТЕІ №136 від 08.05.2015 р.), в рамках якої передбачається обговорення і обмін досвідом щодо вирішення подібних питань серед фахівців.

Таким чином, на підставі аналізу прикладів із судово-фармацевтичної практики вивчено організацію фармацевтичного забезпечення військовослужбовців, які брали участь у бойових діях.

7. Висновки 3 проведеного дослідження і перспективи подальшого розвитку даного напрямку

На підставі узагальнення даних щодо кількості учасників бойових дій, які пройшли лікування в мережі госпіталів по областям України, з'ясовано, що лікуючі позиції займають Київська та Кіровоградська області (відповідно 1506 і 1491 осіб). В ході аналізу судово-фармацевтичної практики (приклад № 1) вивчено досвід лікарів іспанського військового госпіталю щодо надання медико-фармацевтичної допомоги постраждалим військовослужбовцям 3 використанням транексамової кислоти 3 подальшою їх тривалою реабілітацією.

Наведено чинне законодавство України щодо пільгового забезпечення учасників бойових дій лікарськими засобами різних номенклатурно-правових груп. Окремо виділено пільги для учасників бойових дій в сфері охорони здоров'я, передбачені Законом України «Про статус ветеранів війни, гарантії їх соціального захисту».

За результатом судово-фармацевтичних досліджень виявлено проблему несвоєчасного фармацевтичного забезпечення учасників бойових дій на прикладі лікарських засобів актовегін і нормовен (приклад № 2). Встановлено режим контролю зазначених ліків, які за класифікаційно-правовою ознакою відносяться до загальної групи. За номенклатурноправовою ознакою для пацієнтів, які не відносяться до пільгової категорії громадян, актовегін (р-н д/ін.) відпускається за багаторазовим рецептом ф-1, а нормовен - без рецепта, що свідчить про його доступність; для учасників бойових дій зазначені ліки відпускаються за пільговим рецептом ф-1.

Запропоновано організаційно-правові заходи щодо належного забезпечення учасників бойових дій пільгами при отриманні медико-фармацевтичної допомоги в системі охорони здоров'я, зокрема наяв- 
ність кваліфікованих спеціалістів медицини і фармації; збільшення рівня державного фінансування комунальних закладів охорони здоров'я та аптек, а також створення реєстру пільгових категорій хворих (учасників антитерористичної операції).

\section{Література}

1. Барміна, Г. Медико-психологічна та реабілітаційна допомога учасникам АТО [Електронний ресурс] / Г. Барміна // Аптека. - 2015. - Режим доступу: http://www. apteka.ua/article/323836

2. Уляна Супрун: зміна медичної системи - питання національної безпеки [Електронний ресурс]. - Режим доступу: http://www.moz.gov.ua/ua/portal/pre_20160801_b.html

3. Система здравоохранения в зоне АТО в критическом состоянии: ВОЗ [Электронный ресурс]. - Аптека. 2015. - Режим доступа: http://www.apteka.ua/article/319780

4. DeWitt, D. S. Blast-induced brain injury and posttraumatic hypotension and hypoxemia [Text] / D. S. DeWitt, D. S. Prough // Journal of Neurotrauma. - 2009. - Vol. 26, Issue 6. - P. 877-887. doi: 10.1089/neu.2007.0439

5. Пономаренко, М. С. Обгрунтування створення нормативно-визначеного асортименту ліків у відповідності до протоколів провізора і клінічних протоколів медичної допомоги для аптек сімейної фармації та аптек загального типу при закладах сімейної медицини [Текст] / М. С. Пономаренко, А. В. Кабачна, О. С. Соловйов, С. В. Аугунас, B. О. Борищук // ScienceRise. - 2016. - T. 4, № 4 (21). C. 17-22. doi: 10.15587/2313-8416.2016.66967

6. Волох, Д. С. Принципи сучасного управління підприємством фармацевтичного профілю [Текст] / Д. С. Волох, Л. Г. Москаленко, Н. О. Козіко // Фармацевтичний журнал. - 2002. - № 6. - С. 4-7.

7. Загорій, В. А. Багатоваріантність підходу до виробництва і реалізації лікарських засобів як до продуктів ринкової категорії [Текст] / В. А. Загорій, В. В. Огороднік, М. Л. Сятиня, І. С. Веремчук, Т. М. Пономаренко, Т. М. Трубчик // Фармацевтичний журнал. - 2003. - № 1. - С. 3-7.

8. Музика, Т. Ф. Дослідження організації фармацевтичного забезпечення лікувально-профілактичних закладів [Текст] / Т. Ф. Музика, В. М. Толочко, М. В. Зарічкова // Вісник фармації. - 2010. - № 4. - С. 62-65.

9. Гудзенко, О. П. Методичні підходи до регулювання лікарського забезпечення пільгової категорії населення промислових регіонів - хворих раком легенів і молочної залози [Текст] / О. П. Гудзенко // Фармацевтичний журнал. - 2003. - № 4. - С. 23-28.

10. Мнушко, 3. Н. Проблема доступности лекарственных средств [Текст] / 3. Н. Мнушко, И. В. Тиманюк // Провизор. - 2006. - № 11. - С. 4-6.

11. Немченко, А. С. Державне регулювання фармацевтичної діяльності: аналіз діючих переліків лікарських засобів [Текст] / А. С. Немченко, Л. В. Галій // Фармацевтичний журнал. - 2002. - № 4. - С. 31-36.

12. Немченко, А. С. Концепція пріоритетного розвитку соціально-ефективної організації фармацевтичного забезпечення населення та впровадження національних стандартів належних практик GDP та GPP [Текст] / А. С. Немченко, А. А. Котвіцька // Фармацевтичний журнал. 2006. - № 4. - C. 3-10.

13. У мережі госпіталів ветеранів війни вже проліковано близько 13 тис. учасників АТО [Електронний pecypc]. - Режим доступу: http://www.moz.gov.ua/ua/portal/ pre_20160713 a.html

14. Aedo-Martín, D. Use of tranexamic acid in combat casualties. Experience of the Spanish medical corps. Clinical series and literature review [Text] / D. Aedo-Martín, R. GarcíaCañas, R. Navarro-Suay, M. Martínez-Roldán, R. Baños-Turza, R. Tamburri-Bariain // Revista Española de Cirugía Ortopédica y Traumatología (English Edition). - 2016. - Vol. 60, Issue 3 P. 200-205. doi: 10.1016/j.recote.2016.03.006

15. Закон України від 19.11.1992 № 2801-XII «Основи законодавства України про охорону здоров'я» [Текст] // Відомості Верховної Ради України, 1993. - № 4. - Ст. 19.

16. Закон України від 04.04.1996 № 123/96-ВР «Про лікарські засоби» [Текст] // Відомості Верховної Ради України, 1996. - № 22. - Ст. 86.

17. Закон України від 22.10.1993 № 3551-XII «Про статус ветеранів війни, гарантії їх соціального захисту» [Текст] // Відомості Верховної Ради України, 1993. - № 45. - Ст. 425.

18. Закон України від 02.10.1996 № 393/96-ВР «Про звернення громадян» [Текст] // Відомості Верховної Ради України, 1996. - № 47. - Ст. 256.

19. Конституція України від 28.06.1996 № 254к/96ВР [Текст] // Відомості Верховної Ради України, 1996. № 30. - Ст. 141.

20. Наказ МОЗ України від 19.07.2005 № 360 «Про затвердження Правил виписування рецептів та вимогзамовлень на лікарські засоби і вироби медичного призначення, Порядку відпуску лікарських засобів і виробів медичного призначення 3 аптек та їх структурних підрозділів, Інструкції про порядок зберігання, обліку та знищення рецептурних бланків та вимог-замовлень» [Текст] // Офіційний вісник України. - 2005. - № 29. C. $452 .-$ Ст. 1745 .

21. Постанова Кабінету Міністрів України від 05.09.1996 № 1071 «Про порядок закупівлі лікарських засобів закладами та установами охорони здоров'я, що фінансуються 3 бюджету» в ост. ред. від 14.11.2013 № 972 [Текст] // Офіційний вісник України. - 2013. - № 91. - С. 351.

22. Постанова Кабінету Міністрів України від 17.08.1998 № 1303 «Про впорядкування безоплатного та пільгового відпуску лікарських засобів за рецептами лікарів у разі амбулаторного лікування окремих груп населення та за певними категоріями захворювань» [Текст] // Офіційний вісник України. - 1998. - № 33. - С. 61. - Ст. 1241.

23. Фармацевтичне право. Навчальний посібник до аудиторної та позааудиторної роботи з фармацевтичного законодавства за спеціальністю «Фармація» [Текст] / за ред. В. О. Шаповалової, В. В. Шаповалова, В. В. Шаповалова (мол.). - Х., 2008. - 144 с.

24. У Києві проходить Всеукраїнська міжвідомча науково-практична конференція з питань медичного забезпечення АТО [Електронний ресурс]. - Режим доступу: http://www.moz.gov.ua/ua/portal/pre_20160614_c.html

25. Оптимізація підходів до надання психіатричної допомоги відповідно до сучасних потреб учасників бойових дій [Текст]: метод. реком. / за ред. О. В. Богомолець, І. Я. Пінчук, О. В. Друзь, О. О. Хаустова, А. С. Сичевський, А. Є. Горбань та ін. - К., 2014. -44 с.

26. Ізраїльські експерти ознайомилися із організацією процесу реабілітації бійців АТО в Україні [Електронний ресурc]. - Режим доступу: http://www.moz. gov.ua/ua/portal/pre_20160217_c.html

27. Игорь Райнин проинспектировал областную травматологическую больницу [Электронный ресурс]. Режим доступа: http://www.objectiv.tv/100816/131354.html

\section{References}

1. Barmina, H. (2015). Medyko-psykholohichna ta reabilitatsiina dopomoha uchasnykam ATO. Apteka. Available at: http://www.apteka.ua/article/323836

2. Uliana Suprun: zmina medychnoi systemy - pytannia natsionalnoi bezpeky. Available at: http:/www.moz.gov.ua/ua/ portal/pre_20160801_b.html

3. Sistema zdravoohraneniya v zone ATO v kriticheskom sostoyanii: VOZ (2015). Apteka. Available at: http://www. apteka.ua/article/319780 
4. DeWitt, D. S., Prough, D. S. (2009). Blast-Induced Brain Injury and Posttraumatic Hypotension and Hypoxemia. Journal of Neurotrauma, 26 (6), 877-887. doi: 10.1089/ neu.2007.0439

5. Ponomarenko, M. S., Kabachna, A. V., Soloviov, O. S., Auhunas, S. V., Boryshchuk, V. O. (2016). Rationale for creating legislative definide range drugs in accordance with the protocol pharmacists and clinical protocols of medical care for pharmacies and pharmac family pharmacy of common type institutions of family medicine. ScienceRise, 4/4 (21), 17-22. doi: $10.15587 / 2313-8416.2016 .66967$

6. Volokh, D. S., Moskalenko, L. H., Koziko N. O. (2002). Pryntsypy suchasnoho upravlinnia pidpryiemstvom farmatsevtychnoho profiliu. Farmatsevtychnyi zhurnal, 6, 4-7.

7. Zahorii, V. A., Ohorodnik, V. V., Siatynia, M. L., Veremchuk, I. Ie., Ponomarenko, T. M., Trubchyk T. M. (2003). Bahatovariantnist pidkhodu do vyrobnytstva i realizatsii likarskykh zasobiv yak do produktiv rynkovoi katehorii. Farmatsevtychnyi zhurnal, 1, 3-7.

8. Muzyka, T. F., Tolochko, V. M., Zarichkova, M. V. (2010). Doslidzhennia orhanizatsii farmatsevtychnoho zabezpechennia likuvalno-profilaktychnykh zakladiv. Visnyk farmatsii, 4, 62-65.

9. Hudzenko, O. P. (2003). Metodychni pidkhody do rehuliuvannia likarskoho zabezpechennia pilhovoi katehorii naselennia promyslovykh rehioniv - khvorykh rakom leheniv i molochnoi zalozy. Farmatsevtychnyi zhurnal, 4, 23-28.

10. Mnushko, Z. N., Tymaniuk, Y. V. (2006). Problema dostupnosty lekarstvennыkh sredstv. Provyzor, 11, 4-6.

11. Nemchenko, A. S., Halii, L. V. (2002). Derzhavne rehuliuvannia farmatsevtychnoi diialnosti: analiz diiuchykh perelikiv likarskykh zasobiv. Farmatsevtychnyi zhurnal, 4, 31-36.

12. Nemchenko, A. S., Kotvitska, A. A. (2006). Kontseptsiia priorytetnoho rozvytku sotsialno-efektyvnoi orhanizatsii farmatsevtychnoho zabezpechennia naselennia ta vprovadzhennia natsionalnykh standartiv nalezhnykh praktyk GDP ta GPP. Farmatsevtychnyi zhurnal, 4, 3-10.

13. U merezhi hospitaliv veteraniv viiny vzhe prolikovano blyzko 13 tys. uchasnykiv ATO. Available at: http://www.moz.gov.ua/ua/portal/pre_20160713_a.html

14. Aedo-Martín, D., García-Cañas, R., Navarro-Suay, R., Martínez-Roldán, M., Baños-Turza, R., Tamburri-Bariain, R. (2016). Use of tranexamic acid in combat casualties. Experience of the Spanish medical corps. Clinical series and literature review. Revista Española de Cirugía Ortopédica y Traumatología (English Edition), 60 (3), 200-205. doi: 10.1016/j.recote.2016.03.006

15. Basic Laws of Ukraine on Health Care: the Law of Ukraine dated from November 19, 1992, No. 2801-XII (1993). Supreme Council of Ukraine, 4, Article 19.
16. On Medicines: the Law of Ukraine dated from April 04, 1996, No. 123/96-VR (1996). Supreme Council of Ukraine, 22, Article 86.

17. On the status of war veterans, guarantees of their social protection: the Law of Ukraine dated from October 22, 1993, No. 3551-XII (1993). Supreme Council of Ukraine, 45, Article 425

18. On Public Appeals: the Law of Ukraine dated from October 2, 1996, No. 393/96-VR (1996). Supreme Council of Ukraine, 47, Article 256.

19. Constitution of Ukraine dated from June 28, 1996, No. 254к/96-VR (1996). Supreme Council of Ukraine, 30, Article 141.

20. On approval of writing prescriptions for medicines and medical products Procedure dispensing of medicines and medical supplies from pharmacies and their structural units, Instruction on storage, recording and disposal of prescription forms: the order of the Ministry of Health of Ukraine dated from July 19, 2005, No. 360 (2005). Official Bulletin of Ukraine, 29, Article 1745.

21. On the procedure for procurement of drugs schools and health institutions financed from the budget: the Resolution of the Cabinet of Ministers of Ukraine dated from September 5, 1996 No. 1071 (1996). Official Bulletin of Ukraine, 91, Article 351.

22. On Regulation of free and concessional dispensing medicines prescribed by doctors in the case of outpatient treatment of certain groups and in certain categories of diseases: the Resolution of the Cabinet of Ministers of Ukraine dated from August 17, 1998 No. 1303 (1998). Official Bulletin of Ukraine, 33, Article 1241.

23. Shapovalova, V. O., Shapovalova, V. V., Shapovalova, V. V. (mol.) (Ed.) (2008). Farmatsevtychne pravo. Navchalnyi posibnyk do audytornoi ta poza audytornoi roboty $\mathrm{z}$ farmatsevtychnoho zakonodavstva za spetsialnistiu «Farmatsiia». Kharkiv, 144.

24. U Kyievi prokhodyt Vseukrainska mizhvidomcha naukovo-praktychna konferentsiia $\mathrm{z}$ pytan medychnoho zabezpechennia ATO. Available at: http://www.moz.gov.ua/ ua/portal/pre_20160614_c.html

25. Bohomolets, O. V., Pinchuk, I. Ja., Druz', O. V., Haustova, O. O., Sychevs'kyj, A. S., Gorban', A. Je. et. al. (Eds.) (2014). Optymizatsiia pidkhodiv do nadannia psykhiatrychnoi dopomohy vidpovidno do suchasnykh potreb uchasnykiv boiovykh dii. Kyiv, 44.

26. Izrailski eksperty oznaiomylysia iz orhanizatsiieiu protsesu reabilitatsii biitsiv ATO v Ukraini. Available at: http://www.moz.gov.ua/ua/portal/pre_20160217_c.html

27. Igor Raynin proinspektiroval oblastnuyu travmatologicheskuyu bolnitsu. Available at: http://www.objectiv.tv/ 100816/131354.html

Дата надходження рукопису 29.08.2016

Гудзенко Андрій Олександрович, кандидат фармацевтичних наук, кафедра медичного та фармацевтичного права, загальної і клінічної фармації, Харківська медична академія післядипломної освіти, вул. Амосова, 58, м. Харків, Україна, 61176

E-mail: pharm_law@ukr.net

Шаповалов Валентин Валерійович, доктор філософії, кандидат фармацевтичних наук, доцент, кафедра медичного та фармацевтичного права, загальної і клінічної фармації, Харківська медична академія післядипломної освіти, вул. Амосова, 58, м. Харків, Україна, 61176

Семенькова Ольга Володимирівна, кафедра медичного та фармацевтичного права, загальної і клінічної фармації, Харківська медична академія післядипломної освіти, вул. Амосова, 58, м. Харків, Україна, 61176

Шаповалова Вікторія Олексіївна, доктор фармацевтичних наук, професор, завідувач кафедри, кафедра медичного та фармацевтичного права, загальної і клінічної фармації, Харківська медична академія післядипломної освіти, вул. Амосова, 58, м. Харків, Україна, 61176 
Шаповалов Валерій Володимирович, доктор фармацевтичних наук, професор, начальник відділу фармації, департамент охорони здоров’я Харківської обласної державної адміністрації, пл. Свободи, 5, м. Харків, Україна, 61022

Москаленко Дарія Віталіївна, старший лаборант, кафедра медичного та фармацевтичного права, загальної і клінічної фармації, Харківська медична академія післядипломної освіти, вул. Амосова, 58, м. Харків, Україна, 61176

\title{
УДК 615.07:582.998.14:54.062:543.544.3
}

\section{ДОСЛІДЖЕННЯ КОМПОНЕНТІВ ЛЕТКИХ ФРАКЦІЙ РОСЛИННОЇ СИРОВИНИ САЛАТУ ПОСІВНОГО СОРТУ «ЛОЛЛО РОССО»}

\author{
() В. В. Гуцол, І. О. Журавель, І. Г. Гур'єва
}

Рослини є важливим джерелом одержання біологічно активних речовин, які проявляють різноманітну фармакологічну активність. Увагу привертають не лише рослини, які традиційно використовуються з лікувально-профілактичною метою, а й харчові культури, щзо входять до щзоденного рачіону кожної людини. До таких рослин належить салат посівний, щзо вирощується в усьому світі як листова овочева культура.

Мета. Метою нашої роботи було дослідження якісного складу та кількісного вмісту компонентів летких фракцій, одержаних з листя, коренів та насіння салату посівного сорту «Лолло Россо».

Метод. Встановлення якісного складу та кількісного вмісту компонентів летких фракиій салату посівного сорту «Лолло Россо» проводили методом газової хроматографії.

Результати. В результаті проведеного дослідження в леткій фракиії листя салату посівного ідентифіковано та визначено вміст 31 сполуки, коренів - 27, насіння - 24. В усіх видах рослинної сировини салату домінуючою речовиною був сквален.

Висновки. Одержані результати будуть використані при розробиі методик контролю якості на рослинну сировину салату посівного

Ключові слова: салат посівний, Аsteraceае, летка фракція, ідентифікація, кількісне визначення, газова хроматографія

Herbs are important source of biologically active compounds having different types of pharmacological activity. The attention is drawn both to herbs, traditionally used for prevention and treatment of different disorders, and to edible plants included in the every person's daily diet. Lettuce, grown worldwide as leafy vegetables, is among them.

Aim. The aim of our work was quantitative and qualitative determination of the volatile fractions components, obtained from leaves, roots and seeds of «Lollo rosso» lettuce species.

Methods. Gas chromatography was used for quantitative and qualitative determination of the volatile fractions components of «Lollo rosso» lettuce species.

Results. In result of research, in the volatile fraction of lettuce 31 compounds were identified and determined in leaves, 27 compounds were determined in roots, and 24 compounds were determined in seeds. Squalene was dominating substance in all types of the herbal material.

Conclusion. Obtained results can be used for development of the Quality control methods for lettuce herbal material

Keywords: lettuce, Asteraceae, volatile fraction, identification, qualitative determination, gas chromatography

\section{1. Вступ}

Майже всі рослини світу можуть бути потенційним джерелом для пошуку біологічно активних речовин $з$ вираженою терапевтичною активністю. Їх використовують не лише для профілактики, а й для усунення деяких симптомів та лікування різноманітних захворювань.

Фітотерапія популярна у багатьох країнах світу. Встановлено, що всесвітній ринок фітозасобів у 2009 році становив близько 83 мільярдів доларів США. Серед європейських країн за споживанням засобів рослинного походження лідерами є Німеччина, Франція, Італія та Великобританія [1].
2. Постановка проблеми у загальному вигляді, актуальність теми та її зв'язок з важливими науковими чи практичними питаннями

Рослини, які продукують ефірні олії, відносяться до багатьох родин і видів і розповсюджені на всій території земної кулі. Встановлено, що у всьому світі існує близько 350000 видів рослин, 5 \% 3 яких (17500 видів) $\epsilon$ ефіроолійними. Більше 400 видів 3 них переробляється для промислового отримання ефірних олій [2].

Ефірні олії - це складна суміш різних хімічних сполук, які зумовлюють іï фармакологічний ефект. Компоненти ефірних олій проявляють антиоксидантні, протизапальні, антибактеріальні, протигрибкові, 